\title{
Methanandamide diminish the Porphyromonas gingivalis lipopolysaccharide induced response in human periodontal ligament cells
}

Fengqiu Zhang ${ }^{1,2+}$, Burcu Özdemir ${ }^{2,3 \dagger}$, Phuong Quynh Nguyen², Oleh Andrukhov ${ }^{2 *}$ (D) and Xiaohui Rausch-Fan ${ }^{2}$

\begin{abstract}
Background: The endocannabinoid system is involved in the regulation of periodontal tissue homeostasis. Synthetic cannabinoid methanandamide (Meth-AEA) has improved stability and affinity to cannabinoid receptors compared to its endogenous analog anandamide. In the present study, we investigated the effect of methanandamide on the production of pro-inflammatory mediators in primary human periodontal ligament cells ( $\mathrm{hPdLCs}$ ).

Methods: hPdLCs were treated with Meth-AEA for $24 \mathrm{~h}$, and the resulting production of interleukin (IL)-6, IL-8, and monocyte chemotactic protein (MCP)-1 was measured in the absence or the presence of Porphyromonas gingivalis lipopolysaccharide (LPS). Additionally, the effect of Meth-AEA on the proliferation/ viability of hPdLCs was measured by the MTT method.

Results: Methanandamide at a concentration of $10 \mu \mathrm{M}$ significantly inhibited $P$. gingivalis LPS induced production of IL-6, IL-8, and MCP-1. Basal production of IL-6 and IL-8 was slightly enhanced by $10 \mu \mathrm{M}$ Meth-AEA. No effect of MethAEA on the basal production of MCP-1 was observed. Meth-AEA in concentrations up to $10 \mu \mathrm{M}$ did not affect the proliferation/viability of hPdLCs, but significantly inhibited it at a concentration of $30 \mu \mathrm{M}$.

Conclusion: Our study suggests that the inflammatory response in periodontal ligament cells could be influenced by the activation of the cannabinoid system, which might be potentially involved in the progression of periodontal disease.
\end{abstract}

Keywords: Methanandamide, Cell proliferation, Cytokines, Chemokines, Periodontal ligament

\section{Background}

Periodontitis is a biofilm-induced chronic inflammatory disease, which affects teeth supporting structures, including the gingival tissue, periodontal ligament, and alveolar bone [1]. Clinical signs of periodontitis are gingival inflammation,

\footnotetext{
*Correspondence: oleh.andrukhov@meduniwien.ac.at

${ }^{\dagger}$ Fengqiu Zhang and Burcu Özdemir contributed equally to this work.

${ }^{2}$ Division of Conservative Dentistry and Periodontology, University Clinic of Dentistry, Medical University of Vienna, Sensengasse 2a, 1090 Vienna, Austria Full list of author information is available at the end of the article
}

periodontal pocket formation, periodontal tissue destruction, and, in advanced cases, periodontitis might lead to alveolar bone resorption and tooth loss [2]. Gram-negative anaerobic bacteria such as Porphyromonas gingivalis (P. gingivalis) is thought to be one of the primary etiological agents of periodontitis $[3,4]$. $P$. gingivalis possesses multiple virulence factors that could either induce periodontal tissue inflammation or subvert the host immune system $[4,5]$. Lipopolysaccharide (LPS) is one of the most important virulence factors of $P$. gingivalis $[6,7]$.

C C The Author(s). 2020 Open Access This article is licensed under a Creative Commons Attribution 4.0 International License, which permits use, sharing, adaptation, distribution and reproduction in any medium or format, as long as you give appropriate credit to the original author(s) and the source, provide a link to the Creative Commons licence, and indicate if changes were made. The images or other third party material in this article are included in the article's Creative Commons licence, unless indicated otherwise in a credit line to the material. If material is not included in the article's Creative Commons licence and your intended use is not permitted by statutory regulation or exceeds the permitted use, you will need to obtain permission directly from the copyright holder. To view a copy of this licence, visit http://creativecommons.org/licenses/by/4.0/ The Creative Commons Public Domain Dedication waiver (http://creativecommons.org/publicdomain/zero/1.0/) applies to the data made available in this article, unless otherwise stated in a credit line to the data. 
The endocannabinoid (EC) system consists of endocannabinoids and cannabinoid receptor proteins. Endocannabinoids are a family of endogenous lipid neurotransmitter which activates cannabinoid receptors. Several endocannabinoids have been discovered, the most characterized ones are the anandamide (AEA) and 2-arachidonoylglycerol (2AG) [8], which might be produced by various cells like osteoblasts, osteoclasts, and endothelial cells $[9,10]$. Cannabinoid receptors belong to a transmembrane G-protein coupled receptor family. The primary endocannabinoid receptors cannabinoid receptor type 1 (CB1) and cannabinoid receptor type 2 (CB2) are expressed in various cells and tissues and particularly in dental tissues [11]. The EC system is thought to regulate several brain processes; however, actual studies suggest its involvement in the regulation of bone physiology and immune response [12, 13].

Since the endocannabinoid system is involved in the regulation of bone formation and immune response, several recent studies investigated the mutual role of this system in the homeostasis of periodontal tissue under healthy and inflammatory conditions. Both AEA and 2AG are detectable in gingival crevicular fluid, and their level seems to be increased in periodontally diseased individuals $[14,15]$. There are some controversies about the changes in the expression of $\mathrm{CB} 1$ and $\mathrm{CB} 2$ receptors in periodontitis. One study suggests that the expression of CB1 and CB2 is upregulated under pathological conditions [14]. In contrast, another study shows that bacterial inflammation results in the decrease of CB1 expression and the increase of CB2 expression [16]. Activation of the EC system promotes survival and neuronal differentiation of periodontal ligament stem cells [17]. However, the exact role of the EC system in the progression of periodontal disease remains unknown.

Several experimental studies investigate the mutual role of the EC system in the homeostasis of periodontal tissue. In vitro studies show that anandamide stimulates the proliferation of human gingival fibroblasts [15] and diminishes cytokine production by these cells in response to stimulation with $P$. gingivalis LPS [14]. Our recent study shows that AEA and 2-AG have a different effect on $P$. gingivalis LPS induced production of interleukin (IL)-6, IL-8, and monocyte chemoattractant protein (MCP)-1 [18]. Mainly, P. gingivalis LPS induced response was inhibited by AEA and enhanced by 2-AG [18]. An in vivo study using the ligature periodontitis model in rats shows that the local application of AEA decreases the content of tumor necrosis factor-alpha and IL- $1 \beta$ in gingival tissue [19]. The effect of AEA was abolished by the simultaneous application of CB1 and CB2 inhibitors [19]. A recent study suggests that $\mathrm{CB} 1$ receptor might regulate osteogenic differentiation of periodontal ligament cells [20].

One of the significant problems of application of EC, and particularly AEA, in research, is their low aqueous stability, which might doubt the quality of obtained results [21]. This problem can be solved by the development of synthetic analogs of ECs [22]. Methanandamide (Meth-AEA), a synthetic analog of AEA, has a four-fold higher affinity to cannabinoid receptor than AEA itself and additionally exists a high resistance to enzymatic hydrolysis [23]. In comparison with AEA, Meth-AEA is suggested to be more selective for the $\mathrm{CB} 1$ receptor and less selective for the $\mathrm{CB} 2$ receptor [24]. Compared to ECs, the information about the effect of Meth-AEA on periodontal tissue is very limited. Only one report investigated the effect of topical application of Meth-AEA in a LPS induced periodontitis model in rats to date [25]. This study shows that Meth-AEA significantly diminishes alveolar bone loss in this periodontitis model. However, the ability of Meth-AEA to influence the inflammatory response in human cells of the periodontium is still unknown. Therefore, in the present study, we investigated the effect of Meth-AEA on the basal and $P$. gingivalis LPS induced production of some pro-inflammatory mediators by primary human periodontal ligament cells (hPdLCs).

\section{Methods}

Cell culture and reagents

hPdLCs were isolated from periodontal ligament tissue obtained from wisdom molars extracted for orthodontic reasons in healthy individuals similar to the method described earlier [26, 27]. All donors were systematically healthy, aged from 18 to 22 y.o. Periodontal ligament tissue was scraped from the teeth root surface with a scalpel, cut into small pieces and placed into Dulbecco's modified Eagle's medium (DMEM), supplemented with $10 \%$ fetal bovine serum (FBS), streptomycin $(50 \mu \mathrm{g} / \mathrm{ml})$ and penicillin $(100 \mathrm{U} / \mathrm{ml})$ under humidified air atmosphere of $5 \%$ $\mathrm{CO}_{2}$ at $37^{\circ} \mathrm{C}$. Outgrowing cells were collected and further grown in DMEM medium. hPdLCs between the third and sixth passages were used in the experiments.

Commercially available standard LPS from $P$. gingivalis (Invivogene, San Diego, CA, USA), (R)-(+)- Meth-AEA (Tocris Bristol, UK), and human soluble CD14 (Sigma, St. Louis, MO, USA) were used in the present study.

\section{Cell proliferation/viability assay}

Cell proliferation/viability was measured by the MTT method, as described in our previous study [18]. hPdLCs were seeded in 24 well plates at a density of $2 \times 10^{4}$ cells in $500 \mu \mathrm{L}$ of DMEM supplemented with $10 \%$ FBS. After $24 \mathrm{~h}$, the media were replaced with DMEM supplemented with $1 \%$ FBS and containing meth-AEA at concentrations of $0.03,0.1,0.3,1,3,10,30 \mu \mathrm{M}$. The hPdLCs were treated with different meth-AEA concentrations for $24 \mathrm{~h}$, and untreated cells were used as a control. After treatment with Meth-AEA, $100 \mu \mathrm{l}$ of MTT reagent (3-(4,5-dimethylthiazol-2-yl)-2,5-diphenyl-tetrazolium 
bromide, Sigma, St. Louis, MO, USA) were added to each well and plates were incubated at $37^{\circ} \mathrm{C}$ for $2 \mathrm{~h}$. After incubation, media were discarded, $500 \mu \mathrm{l}$ of dimethylsulfoxide were added into each well to solve formed formazan crystals, and $\mathrm{OD}_{550}$ values were measured on a microplate reader (Molecular Devices, Sunnyvale, CA, USA). Cell proliferation/viability experiments were repeated at least three times for each donor with hPdLCs isolated from five different donors.

\section{Effect of meth-AEA on the production of IL-6, IL-8, and MCP- 1 by hPdLCs}

The hPdLCs were seeded in 24 well plate at a density of $5 \times 10^{4}$ cells in $500 \mu \mathrm{L}$ of DMEM supplemented with $10 \%$ FBS. After $24 \mathrm{~h}$, the media were replaced with DMEM supplemented with 1\% FBS and containing Meth-AEA at concentrations of $0.1,1,10 \mu \mathrm{M}$. The hPdLCs were treated with different Meth-AEA concentrations for $24 \mathrm{~h}$, and untreated cells were used as a control. In some experiments, hPdLCs treatment was performed in the presence of $1 \mu \mathrm{g} /$ $\mathrm{ml}$ of $P$. gingivalis LPS and $0.25 \mu \mathrm{g} / \mathrm{ml}$ soluble CD14 (sCD14). As shown by our recent study, sCD14 enhances the response of periodontal ligament cells to bacterial LPS [28] After 24h stimulation, the expression of IL-6, IL-8, and MCP-1 in hPdLCs was measured by real-time PCR. The content of the corresponding protein in conditioned media was assayed by ELISA similarly to the methods described previously $[18,29]$.

Isolation of mRNA from hPdLCs, subsequent transcription to CDNA, and amplification were performed using commercially available TaqMan Gene Expression Cells-toCT kit (Ambion/Applied Biosystems, Foster City, CA, USA), which provides excellent accuracy and superior sensitivity of gene-expression analysis [30]. qPCR was performed on an ABI StepOnePlus device (Applied Biosystems, Foster City, CA, USA) in paired reactions using the Taqman gene expression assays with following ID numbers (all from Applied Biosystems, Foster City, CA, USA): IL-6, Hs00985639_m1; IL-8, Hs00174103_m1; MCP-1, Hs00234140_m1; $\beta 2-$ microglobulin, Hs99999907_m1. Real-time PCR reactions were performed in triplicate in 96-well plates using the following thermocycling conditions: $95^{\circ} \mathrm{C}$ for $10 \mathrm{~min}$; 40 cycles, each for $15 \mathrm{~s}$ at $95^{\circ} \mathrm{C}$ and $60{ }^{\circ} \mathrm{C}$ for $1 \mathrm{~min}$. The point at which the PCR product was first detected above a fixed threshold (cycle threshold, $\mathrm{Ct}$ ), was determined for each sample. Changes in the expression of target genes were calculated using the $2^{-\Delta \Delta C t}$ method [31], where $\Delta \Delta C t=\left(C_{t}^{\text {tar- }}\right.$ get $\left.{ }_{-} C_{t}^{\beta 2-\text {-microglobulin }}\right)_{\text {sample }}-\left(C_{t}^{\text {target }}-C_{t}^{\beta 2-\text { microglobulin }}\right)_{\text {control, }}$ taking an untreated sample as a control.

Content of IL-6, IL-8, and MCP-1 proteins in conditioned media was measured by commercially available ELISA Ready-Set-Go kits (eBioscience, San Diego, CA, USA) according to manufacturer's instruction. Each measurement was performed in duplicates. For measurement of IL-6 and MCP-1, samples were not diluted, whereas, for the measurements of IL-8, samples were diluted 1:10.

\section{Statistical analysis}

The normal distribution of all data was tested with the Kolmogorov-Smirnov test. After confirming normal distribution, the statistical differences between different groups were analyzed by one-way analysis of variance (ANOVA) for repeated measures followed by t-test. Statistical analyses were performed using the statistical program SPSS 21.0 (SPSS, Chicago, IL, USA). Curve fitting and regression analysis were performed with Microsoft Excel (Redmond, WA, USA). Data are expressed as mean \pm S.E.M. of five different donors. Differences were considered to be statistically significant at $p<0.05$.

\section{Results}

Effect of meth-AEA on proliferation/viability of hPdLCs

The effect of Meth-AEA on the proliferation/viability of hPdLCs after $24 \mathrm{~h}$ of stimulation is shown in Fig. 1. It can be seen that Meth-AEA at the concentrations ranging from $0.03-10 \mu \mathrm{M}$ exerted no statistically significant effect on the proliferation/viability of hPdLCs (Fig. 1a, $p>0.05$, ANOVA, post-hoc t-test). Treatment with meth-AEA at a concentration of $30 \mu \mathrm{M}$ induced a significant decrease in hPdLCs proliferation/viability (Fig. 1a, $p<0.001$, ANOVA, post-hoc t-test). The fitting curve with the regression analysis is presented in Fig. 1b.

\section{Effect of meth-AEA on the gene expression of IL-6, IL-8, and MCP-1 in hPdLCs}

Figure 2 shows the effect of Meth-AEA $(0.1-10 \mu \mathrm{M})$ on the gene expression levels of IL-6, IL-8, and MCP-1. No significant effect of Meth-AEA in all tested concentrations on the gene expression levels of IL- 6 and MCP-1 was observed. Gene expression level of IL-8 was not significantly changed by Meth-AEA in concentrations of $0.1-1 \mu \mathrm{M}$ and was significantly increased by Meth-AEA in concentration of $10 \mu \mathrm{M}$.

\section{Effect of meth-AEA on the protein production of IL-6, IL- 8 , and MCP-1 by hPdLCs}

The effect of Meth-AEA on the production of IL-6, IL-8, and MCP-1 proteins by hPdLCs is shown in Fig. 3. As can be seen, no significant effect of Meth-AEA in concentrations of $0.1-10 \mu \mathrm{M}$ on the production of all investigated proteins by hPdLCs was observed. Noteworthy, the content of IL- 6 and IL-8 in conditioned media was increased by about $55-60 \%$ upon stimulation with $10 \mu \mathrm{M}$ Meth-AEA, but this effect did not reach statistical significance $(p=0.069$ for IL-6; $p=0.051$ for IL-8). 

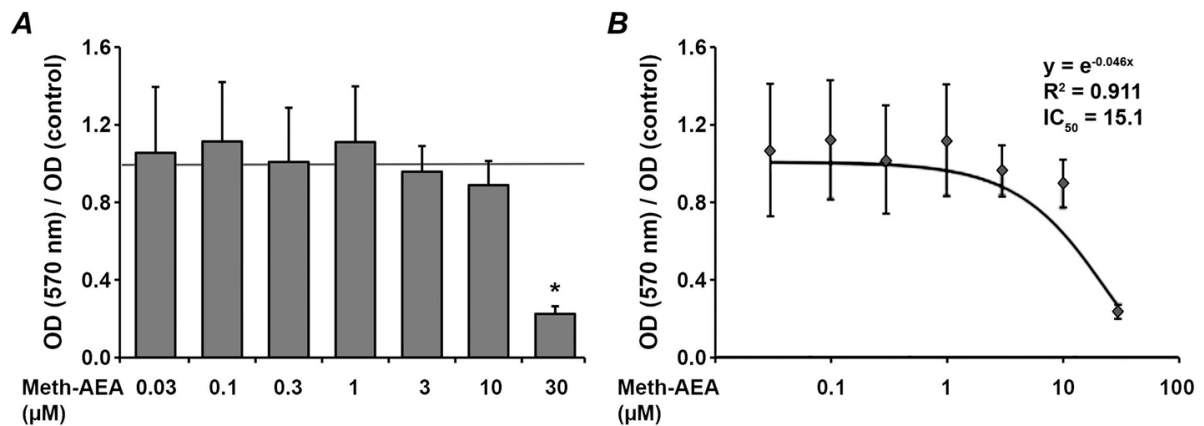

Fig. 1 Effect of Meth-AEA on proliferation/viability of hPdLCs. hPdLCs were stimulated by different Meth-AEA concentrations for $24 \mathrm{~h}$ and the proliferation/viability was measured by the MTT method. $\mathbf{a}-\mathrm{OD}$ values measured at $570 \mathrm{~nm}$ upon stimulation with Meth-AEA are normalized to $\mathrm{OD}$ values measured in the control group (ratio $=1$, shown as horizontal grey line). $\mathbf{b}$ - curve fitting and regression model. Data are shown as the mean \pm s.e.m. of 5 different donors. * means significantly different vs. control group $(p<0.05)$

\section{Effect of meth-AEA on P. gingivalis LPS induced gene expression of IL-6, IL-8, and MCP-1 in hPdLCs}

The effect of Meth-AEA in concentrations of $0.1-10 \mu \mathrm{M}$ on $P$. gingivalis LPS induced gene expression of IL-6, IL8, and MCP-1 in hPdLCs is shown in Fig. 4. P. gingivalis LPS induced a significant increase in the gene expression levels of all pro-inflammatory mediators. $P$. gingivalis LPS induced gene expression levels of IL-6, IL-8, and MCP-1 were significantly decreased by $10 \mu \mathrm{M}$ MethAEA and were not affected by Meth-AEA in lower concentrations.

\section{Effect of meth-AEA on $P$. gingivalis LPS induced} production of IL-6, IL-8, and MCP-1 in hPdLCs

The content of IL-6, IL-8, and MCP-1 in conditioned media of hPdLCs upon stimulation with $P$. gingivalis LPS and different concentrations of Meth-AEA is shown in Fig. 5. P. gingivalis LPS significantly increased the content of all three proteins in the conditioned media.
Meth-AEA at a concentration of $10 \mu \mathrm{M}$ significantly diminished $P$. gingivalis LPS induced production of IL-8 and MCP-1 by hPdLCs, whereas lower Meth-AEA concentration had no significant effect. $P$. gingivalis LPS induced IL- 6 production by hPdLCs was not significantly affected by Meth-AEA in any tested concentration.

\section{Discussion}

Meth-AEA is a highly stable synthetic analog of AEA and, therefore, is widely used in the research on the cannabinoid system $[22,23]$. In the present study, we investigated for the first time the effect of Meth-AEA on the proliferation/viability and inflammatory response in primary hPdLCs in order to further clarify the potential role of the EC system in periodontitis. hPdLCs play an essential role in the maintenance of periodontal tissue homeostasis and possess the immunomodulatory properties [32, 33]. The inflammatory response was assessed by measuring the production of IL-6,- IL-8, and MCP-1,

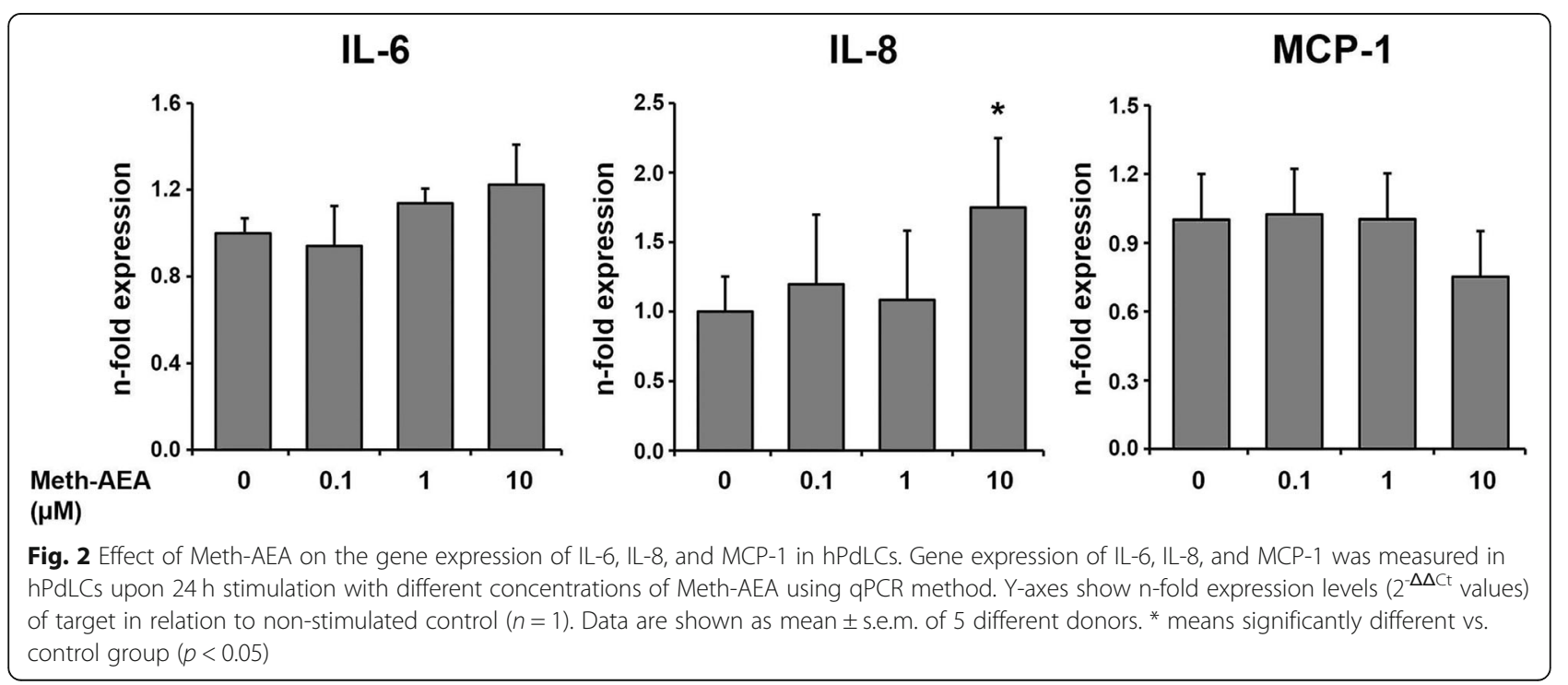



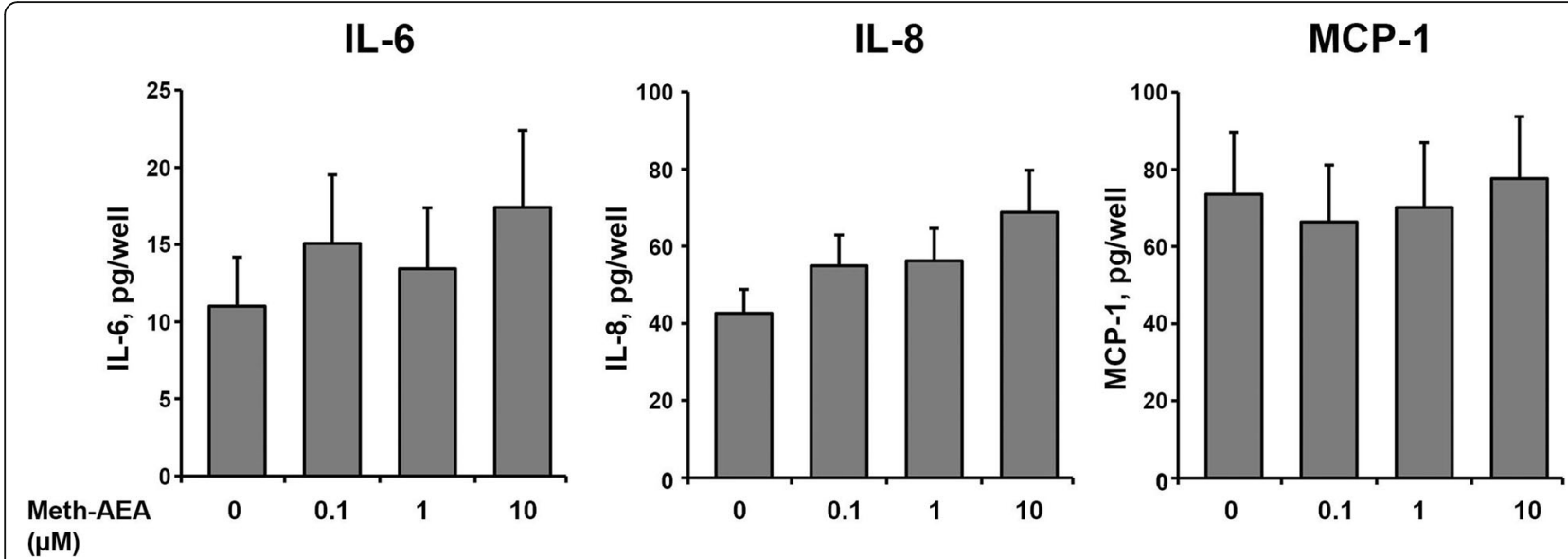

Fig. 3 Effect of Meth-AEA on the production of IL-6, IL-8, and MCP-1 by hPdLCs. The content of IL-6, IL-8, and MCP-1 in conditioned media was measured after $24 \mathrm{~h}$ stimulation with different concentrations of Meth-AEA by commercially available ELISA. Data are shown as mean \pm s.e.m. of 5 different donors

which are involved in the progression of periodontal disease [34-36]. We have focused on these pro-inflammatory mediators because their production in hPdLCs is substantially increased by bacterial LPS [28, 37], whereas the production of other cytokines like IL-1 $\beta$ or tumor necrosis factor $\alpha$ by hPdLCs in response to LPS stimulation is rather low [38].

The proliferation/viability of hPdLCs was not significantly affected by Meth-AEA in concentrations up to $10 \mu \mathrm{M}$ and was inhibited in a concentration of $30 \mu \mathrm{M}$. The effect of Meth-AEA on hPdLCs' proliferation/viability differs from that observed for AEA. In our previous study, we found that AEA slightly stimulates the proliferation/viability of hPdLCs [18]. The exact reason for this discrepancy is not apparent, but it can be due to the different stability of Meth-AEA and AEA in aqueous solutions. Our data on Meth-AEA are in line with a study on prostate cancer cell line showing that Meth-AEA inhibits the proliferation of these cells [39].

Under resting conditions, Meth-AEA in a concentration of $10 \mu \mathrm{M}$ significantly increased the gene expression level of IL-8. Moreover, a similar concentration of MethAEA induced a small, albeit non-significant increase in the production of IL- 6 and IL-8 protein. In agreement with this finding, a study on the prostate cancer cell line also describes the stimulation of IL- 6 production by Meth-AEA [39]. Interestingly, our previous study shows that IL- 6 production by hPdLCs is slightly increased by 2-AG and not influenced by AEA [18]. Under inflammatory conditions, Meth-AEA at a concentration of $10 \mu \mathrm{M}$

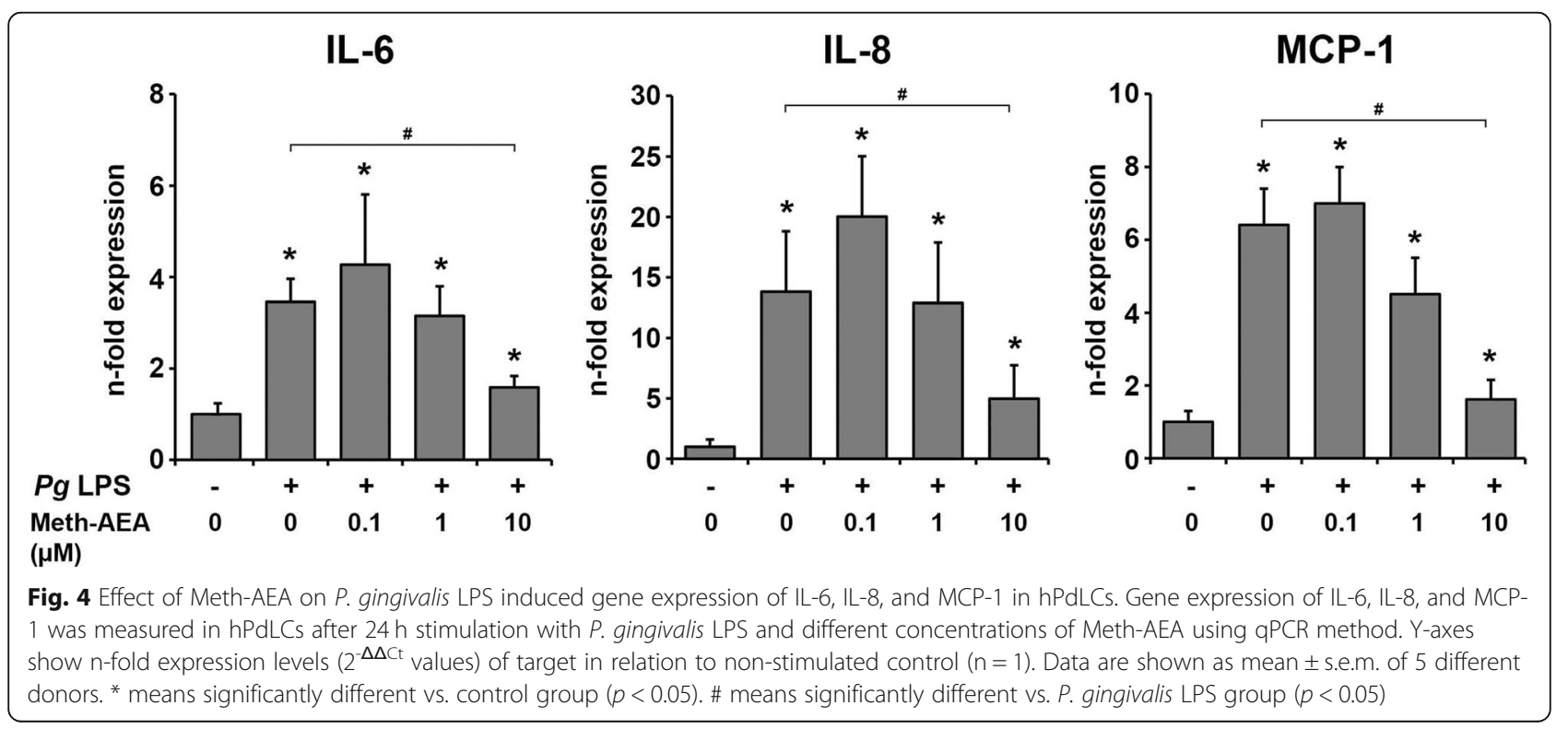



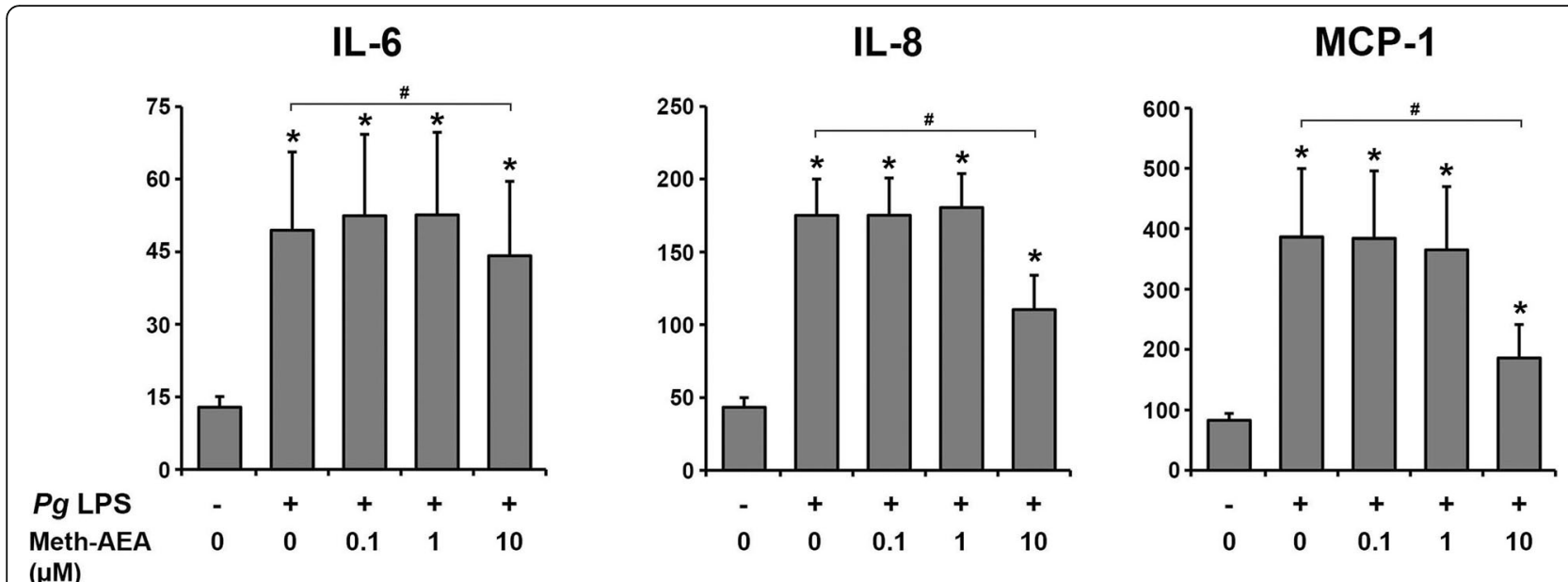

Fig. 5 Effect of Meth-AEA on P. gingivalis LPS induced production of IL-6, IL-8, and MCP-1 by hPdLCs. The Content of IL-6, IL-8, and MCP-1 in conditioned media was measured after $24 \mathrm{~h}$ stimulation with $P$. gingivalis LPS and different concentrations of Meth-AEA by commercially available ELISA. Data are shown as mean \pm s.e.m. of 5 different donors. ${ }^{*}$ means significantly different vs. control group ( $\left.p<0.05\right)$. \# means significantly different vs. $P$. gingivalis LPS group $(p<0.05)$

induced a significant decrease of $P$. gingivalis LPS induced production of IL-6, IL-8, and MCP-1. This effect of Meth-AEA was similar to that of AEA observed in our previous study [18]. The fact that the production of pro-inflammatory mediators is slightly stimulated by Meth-AEA under resting conditions and inhibited under inflammatory conditions suggests a multifaceted role of cannabinoid in the homeostasis of periodontal tissue. An increase in the production of IL- 8 by Meth-AEA under resting conditions could be crucial for the basal activity of the innate immune system, which can, in turn, play an important role in controlling the bacteria growth. Under inflammatory conditions, Meth-AEA can potentially diminish the production of pro-inflammatory mediators by host cells and thus contribute to the protection of host tissues from collateral damages by an excessive inflammatory response.

There are several signaling pathways, which could be potentially involved in the biological effects of Meth-AEA. A biochemical study shows that Meth-AEA exhibits a high affinity for the CB1 receptor, whereas its affinity for the CB2 receptor is rather low [24]. Notably, this study reports that the affinity of Meth-AEA is about $20 \mathrm{nM}$ for CB1 and about $900 \mathrm{nM}$ for the CB2 receptor. In our study, the effects of Met-AEA were observed only for the concentration of $10 \mu \mathrm{M}$, whereas no significant effect was observed for Meth-AEA concentrations up to $1 \mu \mathrm{M}$. Thus, it seems that the effects of Meth-AEA could also be contributed to the activation of the $\mathrm{CB} 2$ receptor.

Interestingly, one study shows that Meth-AEA induces IL-6 secretion by prostate cancer cells, and this effect is inhibited by CB2 receptor antagonist SR144528 and not by CB1 receptor antagonist rimonabant [39]. An antiinflammatory role of $\mathrm{CB} 2$ receptor activation in periodontitis is recently confirmed by a study of LPSinduced periodontitis in rats [40]. Here, the topical application of CB2 receptor agonist HU-308 significantly attenuates the bone loss and inflammatory parameters in this rat model. A recent study shows that different CB2 receptor agonist has an anti-inflammatory effect in human periodontal fibroblasts [41].

A possibility of CB1-independent mechanisms in the biological effects of Meth-AEA cannot be excluded. A study using CB1 receptor knockout mice shows that Meth-AEA exerts physiological effect even in this mice model, which suggests the existence of CB1-independent effects of Meth-AEA [42]. The most investigated CB1independent effect of Meth-AEA is its ability to activate the transient receptor potential vanilloid type-1 receptor (TRPV1). A contribution of this mechanism into the antiinflammatory effect of Meth-AEA cannot be neglected because the ablation of TRPV1 in mice results in exacerbated immune response [43]. However, there are also some CB1independent and TRPV1 independent effects of Meth-AEA [44]. Particularly, Meth-AEA is shown to interact with the muscarinic acetylcholine receptors [45]. Nevertheless, the role of CB1-independent mechanisms in the effect of Meth-AEA in hPdLCs is not known and must be further clarified.

The EC system can be speculated to mediate a link between stress and periodontitis. Stress is a significant risk factor influencing the immune system and potentially contributing to the progression of periodontitis [46, 47]. The EC system plays an essential role in the stress response [48]. Recently, the EC system is suggested as an important part of the neuroimmunoendocrine response in periodontal disease [49]. Our data, as well as data of previous studies $[11,14,15,18,19]$, suggest that the EC 
system influences the inflammatory response in periodontitis. Emotional stress is associated with increased salivary levels of IL-6 and IL-8 [50]. Acute psychological stress is associated with the decreased tissue content of AEA in the brain, which is presumably due to an increased AEA hydrolysis [51]. It can be hypothesized that stress can also influence the levels of endocannabinoids in periodontal tissues and thus modulate their effect on the inflammatory response. However, the exact role of the EC system in the association between stress and periodontal disease should be further investigated.

The limitations of our study originate mainly from the in vitro design. We have used only one cell type and $P$. gingivalis LPS as a single inflammatory stimuli. Situation in vivo is markedly complicated and includes the interaction of several cell types in the presence of numerous inflammatory mediators and bacterial stimuli. The number of donors is rather small, and all donors were young, and therefore our results could not be representative for the whole population. We have used the cells isolated from the third molar, which also restrains the clinical translation because of the limited involvement of these teeth into masticatory function.

\section{Conclusion}

Summarizing, our results on Meth-AEA provide further evidence of the involvement of the EC system into the progression of periodontal disease. Our data are in line with a study on rats showing that Meth-AEA reduces the clinical parameters in LPS-induced periodontitis [25]. Similarly, a local injection of AEA reduced ligature induced periodontitis in rats [19]. An involvement of the EC system in periodontitis is also suggested by studies on cannabinoid receptor expression in periodontal tissue. An in vivo study on human periodontal biopsies shows that periodontitis is associated with a decreased expression of $\mathrm{CB} 1$ receptor and an increased expression of $\mathrm{CB} 2$ receptor [11]. Another study shows an increased expression of $\mathrm{CB} 1$ and $\mathrm{CB} 2$ receptors in inflamed gingival tissue [14]. All these data suggest that the EC system plays an essential role in periodontitis.

\section{Abbreviations \\ LPS: Lipopolysaccharide; Meth-AEA: Methanandamide; hPdLCs: Human periodontal ligament cells; IL: Interleukin; MCP: Monocyte chemoattractant protein; AEA: Anandamide; 2-AG: 2-arachidonoylglycerol; \\ EC: Endocannabinoid; CB1: Cannabinoid receptor type 1; CB2: Cannabinoid receptor type 2; DMEM: Dulbecco's modified Eagle's medium; FBS: Fetal bovine serum; sCD14: Soluble CD14}

\section{Acknowledgements}

Not applicable.

\section{Authors' contributions}

F.Z., B.Ö., O.A., designed experiments; F.Z., B.Ö. P.Q.N. performed experiments; O.A., X.R. analysed results; F.Z., B.Ö., O.A., X.R. wrote the manuscript; all authors approved the manuscript.

\section{Funding}

The study was supported by Authors Institution and grant from the Beijing Natural Science Foundation (7192076 to F.Z.).

\section{Availability of data and materials}

The datasets used and/or analyzed during the current study are available from the corresponding author on reasonable request.

\section{Ethics approval and consent to participate}

The study protocol was approved by the Ethics Committee of the Medical University of Vienna (ethical approval number: 1694/2015). The methods were carried out in accordance with the relevant guidelines and regulations; all patients got informed before the surgical procedure and gave their written consent.

\section{Consent for publication \\ Not applicable.}

\section{Competing interests}

The authors declare that they have no conflicts of interest.

\section{Author details}

${ }^{1}$ Department of Periodontology, Capital Medical University School of Stomatology, Beijing, China. ${ }^{2}$ Division of Conservative Dentistry and Periodontology, University Clinic of Dentistry, Medical University of Vienna, Sensengasse 2a, 1090 Vienna, Austria. ${ }^{3}$ Department of Periodontology, Faculty of Dentistry, Gazi University, Ankara, Turkey.

Received: 2 July 2019 Accepted: 25 March 2020

Published online: 15 April 2020

\section{References}

1. Kinane DF, Attstrom R. Advances in the pathogenesis of periodontitis. Group B consensus report of the fifth European Workshop in Periodontology. J Clin Periodontol. 2005;32(Suppl 6):130-1.

2. Kinane DF, Stathopoulou PG, Papapanou PN. Periodontal diseases. Nat Rev Dis Primers. 2017:3:17038.

3. Socransky SS. Haffajee AD (2005) Periodontal microbial ecology. Periodontol. 2000;38:135-87.

4. Hajishengallis G. Periodontitis: from microbial immune subversion to systemic inflammation. Nat Rev Immunol. 2015;15:30-44.

5. Holt SC, Kesavalu L, Walker S, Genco CA. Virulence factors of Porphyromonas gingivalis. Periodontol 2000. 1999;20:168-238.

6. Bainbridge BW, Coats SR, Darveau RP. Porphyromonas gingivalis lipopolysaccharide displays functionally diverse interactions with the innate host defense system. Ann Periodontol. 2002;7:29-37.

7. How KY, Song KP, Chan KG. Porphyromonas gingivalis: an overview of Periodontopathic pathogen below the gum line. Front Microbiol. 2016;7:53.

8. Kreitzer FR, Stella N. The therapeutic potential of novel cannabinoid receptors. Pharmacol Ther. 2009;122:83-96.

9. Bab I, Ofek O, Tam J, Rehnelt J, Zimmer A. Endocannabinoids and the regulation of bone metabolism. J Neuroendocrinol. 2008;20(Suppl 1):69-74.

10. Opitz CA, Rimmerman N, Zhang Y, Mead LE, Yoder MC, et al. Production of the endocannabinoids anandamide and 2-arachidonoylglycerol by endothelial progenitor cells. FEBS Lett. 2007;581:4927-31.

11. Konermann A, Jager A, Held SA, Brossart P, Schmole A. In vivo and in vitro identification of Endocannabinoid signaling in periodontal tissues and their potential role in local pathophysiology. Cell Mol Neurobiol. 2017.

12. Idris Al, Ralston SH. Cannabinoids and bone: friend or foe? Calcif Tissue Int. 2010;87:285-97.

13. Cabral GA, Rogers TJ, Lichtman AH. Turning over a new leaf: cannabinoid and Endocannabinoid modulation of immune function. J Neurolmmune Pharmacol. 2015;10:193-203.

14. Nakajima Y, Furuichi Y, Biswas KK, Hashiguchi T, Kawahara K, et al. Endocannabinoid, anandamide in gingival tissue regulates the periodontal inflammation through NF-kappaB pathway inhibition. FEBS Lett. 2006;580: 613-9.

15. Kozono S, Matsuyama T, Biwasa KK, Kawahara K, Nakajima Y, et al. Involvement of the endocannabinoid system in periodontal healing. Biochem Biophys Res Commun. 2010;394:928-33. 
16. Nazir MA. Prevalence of periodontal disease, its association with systemic diseases and prevention. Int J Health Sci (Qassim). 2017;11:72-80.

17. Lanza Cariccio V, Scionti D, Raffa A, lori R, Pollastro F, et al. Treatment of periodontal ligament stem cells with MOR and CBD promotes cell survival and neuronal differentiation via the PI3K/Akt/mTOR pathway. Int J Mol Sci. 2018;19.

18. Ozdemir B, Shi B, Bantleon HP, Moritz A, Rausch-Fan X, et al. Endocannabinoids and inflammatory response in periodontal ligament cells. PLoS One. 2014;9:e107407.

19. Rettori E, De Laurentiis A, Zorrilla Zubilete M, Rettori V, Elverdin JC. Anti-inflammatory effect of the endocannabinoid anandamide in experimental periodontitis and stress in the rat. Neuroimmunomodulation. 2012;19:293-303.

20. Yan W, Cao Y, Yang H, Han N, Zhu X, et al. CB1 enhanced the osteo/ dentinogenic differentiation ability of periodontal ligament stem cells via p38 MAPK and JNK in an inflammatory environment. Cell Prolif. 2019;52: e12691.

21. Jarho P, Urtti A, Jarvinen K, Pate DW, Jarvinen T (1996) Hydroxypropyl-betacyclodextrin increases aqueous solubility and stability of anandamide. Life Sci 58: PL 181-185.

22. Palmer SL, Khanolkar AD, Makriyannis A. Natural and synthetic endocannabinoids and their structure-activity relationships. Curr Pharm Des. 2000;6:1381-97.

23. Abadji V, Lin S, Taha G, Griffin G, Stevenson LA, et al. (R)-methanandamide: a chiral novel anandamide possessing higher potency and metabolic stability. J Med Chem. 1994;37:1889-93.

24. Goutopoulos A, Fan P, Khanolkar AD, Xie XQ, Lin S, et al. Stereochemical selectivity of methanandamides for the CB1 and CB2 cannabinoid receptors and their metabolic stability. Bioorg Med Chem. 2001;9:1673-84.

25. Ossola CA, Surkin PN, Pugnaloni A, Mohn CE, Elverdin JC, et al. Long-term treatment with methanandamide attenuates LPS-induced periodontitis in rats. Inflamm Res. 2012;61:941-8.

26. Behm C, Blufstein A, Gahn J, Noroozkhan N, Moritz A, et al. Soluble CD14 enhances the response of periodontal ligament stem cells to toll-like receptor 2 agonists. Mediat Inflamm. 2019;2019:8127301.

27. Blufstein A, Behm C, Gahn J, Uitz O, Naumovska I, et al. Synergistic effects triggered by simultaneous toll-like receptor-2 and -3 activation in human periodontal ligament stem cells. J Periodontol. 2019:90:1190-201.

28. Andrukhov $\mathrm{O}$, Andrukhova O, Ozdemir B, Haririan H, Muller-Kern M, et al. Soluble CD14 enhances the response of periodontal ligament stem cells to P. gingivalis lipopolysaccharide. PLoS One. 2016;11:e0160848.

29. Andrukhov O, Hong JS, Andrukhova O, Blufstein A, Moritz A, et al. Response of human periodontal ligament stem cells to IFN-gamma and TLR-agonists. Sci Rep. 2017;7:12856.

30. Van Peer G, Mestdagh P, Vandesompele J. Accurate RT-qPCR gene expression analysis on cell culture lysates. Sci Rep. 2012;2:222.

31. Livak KJ, Schmittgen TD. Analysis of relative gene expression data using real-time quantitative PCR and the 2(-Delta Delta $C(T)$ ) method. Methods. 2001;25:402-8

32. Andrukhov O, Behm C, Blufstein A, Rausch-Fan X. Immunomodulatory properties of dental tissue-derived mesenchymal stem cells: implication in disease and tissue regeneration. World J Stem Cells. 2019;11(9):604-17.

33. Behm C, Blufstein A, Gahn J, Kubin B, Nemec M, et al. 1,25(OH)2D3 differently affects Immunomodulatory activities of Mesenchymal stem cells depending on the presence of TNF-alpha, IL-1beta and IFN-gamma. J Clin Med. 2019;8.

34. Nibali L, Fedele S, D'Aiuto F, Donos N. Interleukin-6 in oral diseases: a review. Oral Dis. 2012;18:236-43.

35. Kurtis B, Tuter G, Serdar M, Akdemir P, Uygur C, et al. Gingival crevicular fluid levels of monocyte chemoattractant protein-1 and tumor necrosis factor-alpha in patients with chronic and aggressive periodontitis. J Periodontol. 2005;76:1849-55.

36. Finoti LS, Nepomuceno R, Pigossi SC, Corbi SC, Secolin R, et al. Association between interleukin-8 levels and chronic periodontal disease: a PRISMAcompliant systematic review and meta-analysis. Medicine (Baltimore). 2017; 96:e6932.

37. Blufstein A, Behm C, Nguyen PQ, Rausch-Fan X, Andrukhov O. Human periodontal ligament cells exhibit no endotoxin tolerance upon stimulation with Porphyromonas gingivalis lipopolysaccharide. J Periodontal Res. 2018.

38. Albiero ML, Amorim BR, Martins L, Casati MZ, Sallum EA, et al. Exposure of periodontal ligament progenitor cells to lipopolysaccharide from
Escherichia coli changes osteoblast differentiation pattern. J Appl Oral Sci. 2015:23:145-52.

39. Olea-Herrero N, Vara D, Malagarie-Cazenave S, Diaz-Laviada I. The cannabinoid R+ methanandamide induces IL-6 secretion by prostate cancer PC3 cells. J Immunotoxicol. 2009;6:249-56.

40. Ossola CA, Surkin PN, Mohn CE, Elverdin JC, Fernandez-Solari J. Antiinflammatory and Osteoprotective effects of Cannabinoid-2 receptor agonist HU-308 in a rat model of lipopolysaccharide-induced periodontitis. J Periodontol. 2016:87:725-34

41. Abidi AH, Presley CS, Dabbous M, Tipton DA, Mustafa SM, et al. Antiinflammatory activity of cannabinoid receptor 2 ligands in primary hPDL fibroblasts. Arch Oral Biol. 2018;87:79-85.

42. Baskfield CY, Martin BR, Wiley JL. Differential effects of delta9tetrahydrocannabinol and methanandamide in CB1 knockout and wild-type mice. J Pharmacol Exp Ther. 2004;309:86-91.

43. Wang $Y$, Wang DH. TRPV1 ablation aggravates inflammatory responses and organ damage during endotoxic shock. Clin Vaccine Immunol. 2013;20: 1008-15.

44. Roberts LA, Ross HR, Connor M. Methanandamide activation of a novel current in mouse trigeminal ganglion sensory neurons in vitro. Neuropharmacology. 2008:54:172-80.

45. Christopoulos A, Wilson K. Interaction of anandamide with the $M(1)$ and M(4) muscarinic acetylcholine receptors. Brain Res. 2001;915:70-8.

46. Warren KR, Postolache T, Groer ME, Pinjari O, Kelly DL, et al. Role of chronic stress and depression in periodontal diseases. Periodontol. 2014;2000(64): 127-38.

47. Haririan H, Andrukhov O, Bottcher M, Pablik E, Wimmer G, et al. Salivary neuropeptides, Stress and Periodontitis. J Periodontol. 2017:1-15.

48. Riebe CJ, Wotjak CT. Endocannabinoids and stress. Stress. 2011;14:384-97.

49. Rettori E, De Laurentiis A, Dees WL, Endruhn A, Rettori V. Host neuroimmuno-endocrine responses in periodontal disease. Curr Pharm Des. 2014; 20:4749-59.

50. Shields GS, Kuchenbecker SY, Pressman SD, Sumida KD, Slavich GM. Better cognitive control of emotional information is associated with reduced proinflammatory cytokine reactivity to emotional stress. Stress. 2016;19:63-8.

51. Morena M, Patel S, Bains JS, Hill MN. Neurobiological interactions between stress and the Endocannabinoid system. Neuropsychopharmacology. 2016; 41:80-102.

\section{Publisher's Note}

Springer Nature remains neutral with regard to jurisdictional claims in published maps and institutional affiliations.

\section{Ready to submit your research? Choose BMC and benefit from:}

- fast, convenient online submission

- thorough peer review by experienced researchers in your field

- rapid publication on acceptance

- support for research data, including large and complex data types

- gold Open Access which fosters wider collaboration and increased citations

- maximum visibility for your research: over $100 \mathrm{M}$ website views per year

At BMC, research is always in progress.

Learn more biomedcentral.com/submissions 